\title{
The Polyaniline Electrode Doped with Li Salt and Protonic Acid in Lithium Secondary Battery
}

\author{
Kwang Sun Rỵu, Kwang Man Kim, Young-Sik Hong, Yong Joon Park, and Soon Ho Chang \\ Electronicis of Telecommancations Research lnwitute (FTRI), Daejeon 305-350, Korea \\ Recined.1/arch 27, 2002
}

\begin{abstract}
We prepared the polyaniline (Pani) film and powder by chemical poly merization and doping with different dopants and also investigated the capability of $\mathrm{Li} /$ polyaniline cells after assembling. The oxidation/reduction potentials and electrochemical reaction of $\mathrm{Li} /$ polyaniline cells were tested by cyclic voltanumetry technique. The $\mathrm{Li} / \mathrm{Pani}-\mathrm{HCl}$ cells with $10 \%$ and $20 \%$ conductors show a little larger specific discharge capacities than that without conductor. The highest discharge capacity of almost $50 \mathrm{mAl} / \mathrm{g}$ at $100^{\text {th }}$ cycle is also achieved. However. $\mathrm{Li} / / \mathrm{Pani}-\mathrm{LiPF}_{6}$ with $20 \%$ conductor shows a remarkable perfomance of $\sim 90 \mathrm{mLAl} / \mathrm{g}$ at $100^{\text {th }} \mathrm{cycle}$. This is feasible value for using as the positive electrode material of lithium ion secondary batteries. It is also proved that the powder type electrode of Pani is better to use than the film type one to improve the specific discharge capacity and its stability with cycle.
\end{abstract}

Key words: Lithium battery. Polỵmer clectrode. Conducting poly mer. Polyaniline. Li salt doping

\section{Introduction}

The conducting polymer is an unique one. which has $\pi$ conjugated electrons spread along its backbone and contains delocalized electron structure after doping. Conducting and semiconducting polymers have received immense attention since the discovery of high conductivity in doped polyacetylene. These polymers such as polyaniline (Pani). polypyrrole (Ppy), polythiophene (Pth) etc. have greatly dominated the field of conducting and semiconducting polymers. Most of the researchers in this field have concentrated on the applications of conducting polymers in batteries. ${ }^{--4}$ electronic/optoelectronic devices like solar cells. " photoconductors, electrochromic displays. ${ }^{5}$ and field effect transistors ${ }^{7}$ etc.

Lithium secondary battery is one of the most important applications of conducting polymers. Pani. Ppy, and Pth are particularly expected to be active electrode materials for lithium secondary battery because they are stable in air and have good electrochemical properties. The use of conducting polymers as electrodes in battery relies on their electrochemical redox (doping/dedoping) processes. A given polymer can be repeatedly crcled between different oxidation states. thereby acting as a reversible electrode for a rechargeable battery. Although in principle conducting polymers can be used both as anode (i.e. by exploiting their reduction or ndoping process) and cathode (i.e. by oxidation or p-doping). most battery applications are confined to the latter case. ${ }^{\text {" }}$

The electrochemical process as in most of the $\mathrm{Li} / /$ conducting polymer batteries. involves the electrolyte salt to an extent that is defined by the doping level " $y$ ", i.e. the extent of the oxidation state reached by the polymer electrode. Thus, the doping level is proportional to the

\footnotetext{
"Cotresponding author. T'el: +82-42-860-5517: Fax.: +82-42860-6836: F-mail: ruksidetri.re.kr
}

amount of charge involved and directly related to battery capacity (mAh).

Another particular feature of $\mathrm{Li} /$ conducting polymer batteries is that the electrode kinetics is generally controlled by the diffusion of the dopant anions throughout the polymer structure. As expected the charge-discharge rate of polymer electrodes greatly depends upon the nature (size and charge density) of the dopant anion and upon electrode morphology. Therefore, the synthetic condition of conducting polymer becomes very important for the capability of electrode in battery. The polymer electrode configuration retains such specific advantage as flexibility in geometry and design. compatibility with the enviromment and projected low cost. factors that make them competitive for small sized. low rate button prototypes for the microelectronics consumer market.

The possible application as battery electrodes of Pani was first reported in 1968. "1) However. the study of its use in electrodes only began in the $1980 \mathrm{~s}$. after the feasibility of conductive polymers as battery electrode was demonstrated. After that. many results were reported about the Pani electrodes that were synthesized with electrochemical or chemical methods. ${ }^{11-1.3}$

However. although the Pani doped with protonic acid was well known. the Panu doped with lithiun salt had been rarely studied for use as the positive electrode material of secondary battery. We reported the lithium salt-doped Pani samples prepared by the inmersion of emeraldine base (EB) into the electrolyte solutions containing lithiun salt. Moreover the possibility of the lithium salt-doped Pani films as electrode in battery was also reported ${ }^{14.1 .5}$

In the present work. we prepared the Pani powder with chemical polvmerization and doped with $\mathrm{HCl}$ or $\mathrm{LiPF}_{6}$. The capability of $\mathrm{L} /$ /Pani powder investigated with different contents of conductor. In addition. the charge-discharge characteristics of $\mathrm{Li} / / \mathrm{Pani}-\mathrm{HCl}$ and $\mathrm{Li} / / \mathrm{Pani}_{-} \mathrm{LiPF}_{6 .}$ as in 
powder and film forms. are also investigated and their capabilitics are also compared.

\section{Experimental Section}

The sy nthesis and doping with $\mathrm{HCl}$ for Pani powder were already reported elsewhere. ${ }^{1617}$ For the fabrication of Pani film. EB powder was dissolved in $\mathrm{N}$-methy 1-2-py rrolidinone solvent. and the weight ratio of EB was $3 \%$ with respect to the solvent. The solution was poured on a slide glass and dried at $80^{\circ} \mathrm{C}$ in a convection oven to prepare EB freestanding film. For the ionic salt doping of Pani powder. ethylene carbonate (EC) and dimethyl carbonate (DMC) (battery grade. Mitsubishi Chentical Co.) as solvents. and $\mathrm{LiPF}_{6}$ (Aldrich) as lithium salt were used. The EB powder was immersed in $1 \mathrm{M} \mathrm{LiPF}_{6}$ solution in EC/DMC ( 1 : volume ratio) for $72 \mathrm{~h}$ in a dry room. After that. the doped powder was washed with ethyl ether and dried for $15 \mathrm{~h}$ at 60 "C under vacuum.

For measuring de conductivity. a four-probe method was used. Four thin gold wires $(0.1$ mm thick and $99.95 \%$ purc gold) were attached in parallel on the sample surface by graphite glue (Acheson Electrodag 502) to eliminate contact resistance.

The electrochemical cell consisted of conducting polymer powders as the active matcrial of positive clcctrode. porous polypropy lene/polycthylenc/polypropy lene film (cclgard) as scparator. Jithium metal as negative electrode. and I M LiPF dissolved in $1: 1$ (volume ratio) mixture of EC and DMC as electrolyte solution. The positive clectrode was prepared from the viscous mixture of conducting polymer synthesized. poly(tetrafluorocthylenc) binder. and carbon black

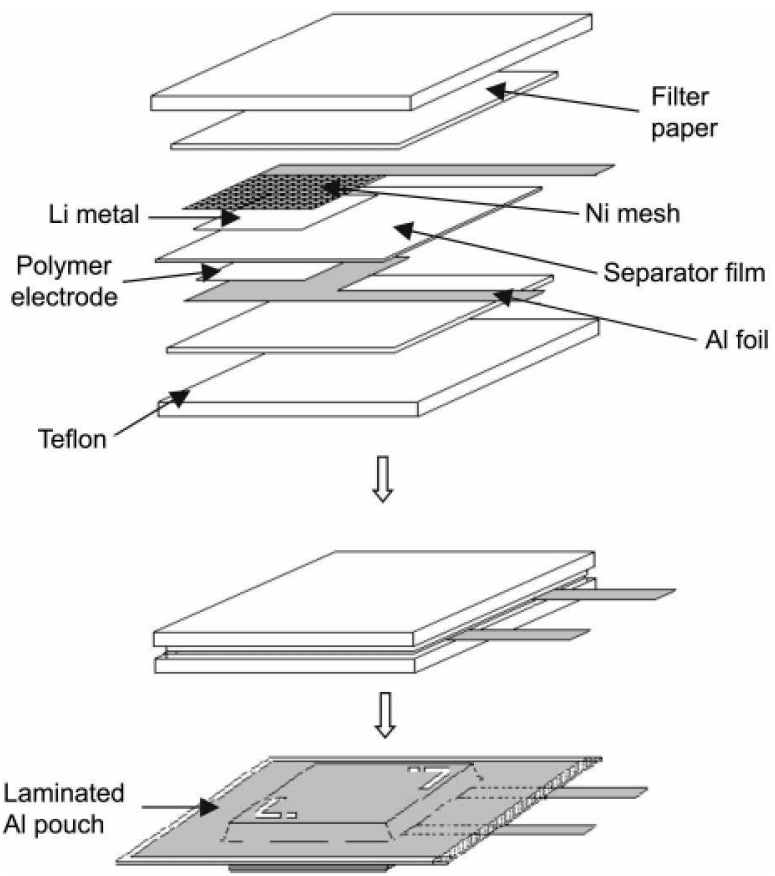

Figure 1. The components and assembling sequence of the cell using conducting polymer as electrode. conductor powder (Super P. MMM Carbon Co.) (100: 10:0 20 in weight basis), respectively. The charge collector (Al foil), polymer clectrode. scparator/clectrolyte solution. lithium metal electrode. and charge collector ( $\mathrm{Ni}$ mesh) were assembled in sequence as a sandwich and cnecloped in a laminated-aluminum pouch within a dry room (sce Figure 1). which was rectangular type $(2 \mathrm{~cm} \times 2 \mathrm{~cm})$ adequate to measure the charge-discharge characteristics. The cells were tested by using a galvanostatic charge-discharge cycler in the voltage range of $2.0-4.0 \mathrm{~V}$ with the constant current density of 0.05 or $0.125 \mathrm{~mA} / \mathrm{cm}^{2}$ with resting at open circuit voltage condition for 30 min alter every charging.

Cyclic voltanmogram was also obtaincd using a MacPilcII potentiostat system at a constant scan rate of $1 \mathrm{mV} / \mathrm{sec}$ in the range of 2.0 to $4.3 \mathrm{~V}$.

\section{Results and Discussion}

In order to identify oxidation/reduction potentials and electrochemical reaction of the cell. cyclic voltammetry was performed for Pani-HCl and Pani-LiPF o powder cell. The oxidation and reduction peaks of these systems occur within $\sim 1.8104 .3 \mathrm{~V}$ and show good reversibility in Figure 2. For Pani- $\mathrm{HCl}$ system. the upper two broad peaks ( $\sim 3.6$ and $\sim 4.1$ $\mathrm{V})$ arc corresponding to the oxidation ( $\mathrm{H}^{\prime}$ or $\mathrm{Cl}^{-}$doping) and the lower threc broad peaks $(\sim 3.9 . \sim 2.8$. and $\sim 2.3 \mathrm{~V})$ the
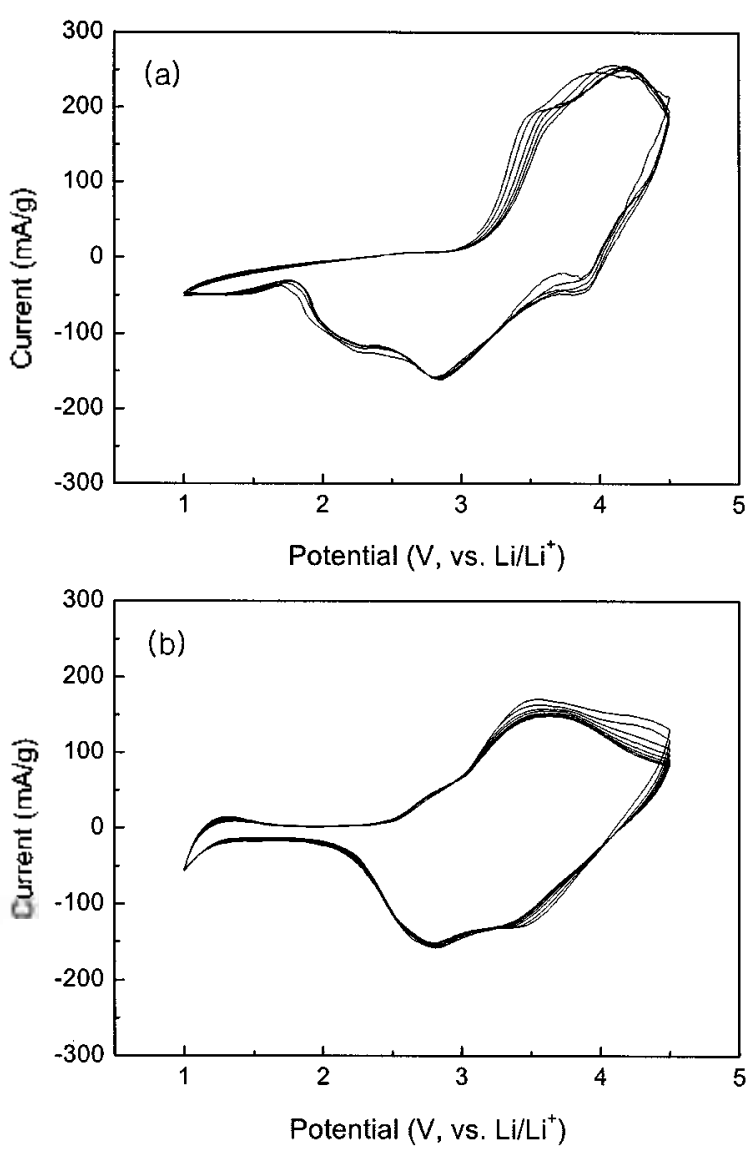

Figure 2. Cyclic voltammogram of (a) Pani-HCl and (b) PaniI.iPF, powder electrode systems. 

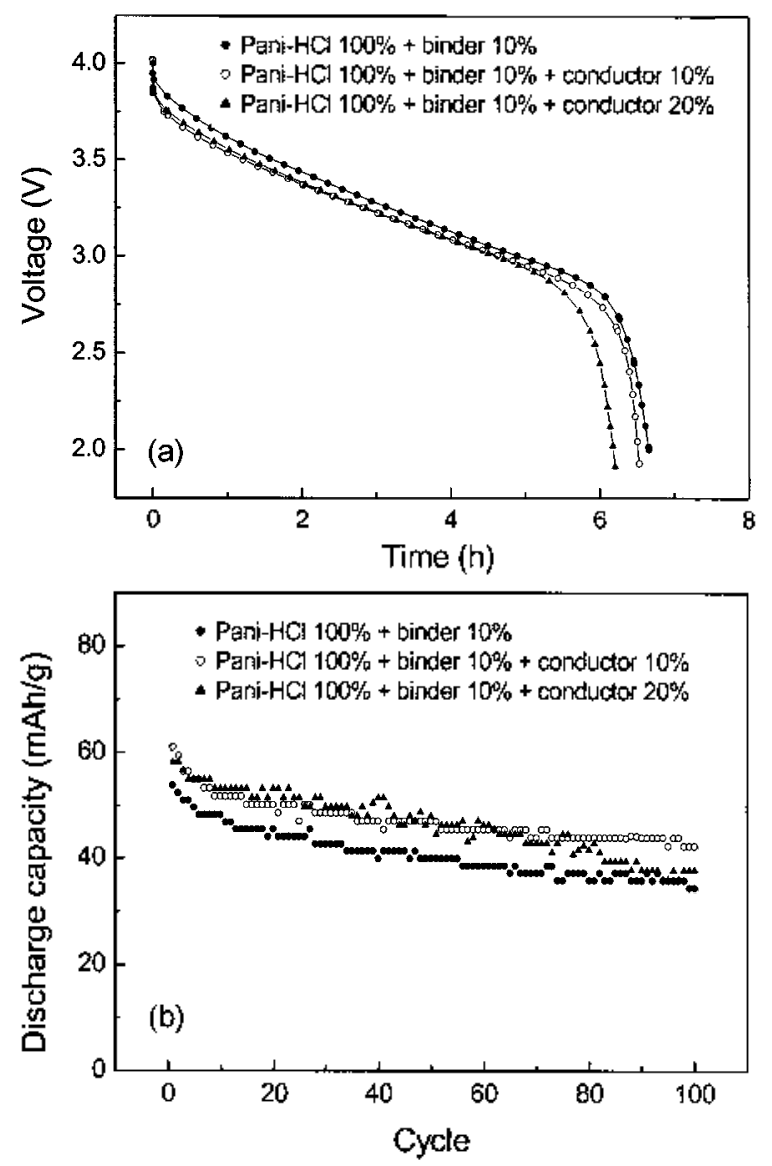

Figure 3. (a) Dischatge curves and (b) cycle life of $\mathrm{T}, \mathrm{i} / \mathrm{Tani}-\mathrm{HCl}$ powder when cycle at $0.05 \mathrm{~m} / \mathrm{N} / \mathrm{cm}^{2}$. The amounts of electrodes are

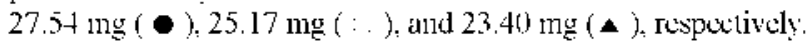

reduction $\left(\mathrm{H}^{\prime}\right.$ or $\mathrm{Cl}^{-}$dedoping). The irreversible process. which the intensity decreases at $\sim 3.6 \mathrm{~V}$ in Figure 2(a). contains initial irreversible elcctrochemical reaction in Pani$\mathrm{HCl}$ system. This irreversible process will cause the decay of initial capacity in this system. Howerer. there are one broad peak and two broad pcaks in Pani-LiPF 6 system. The upper peak $(\sim 3.6 \mathrm{~V})$ is corresponding to the oxidation $\left(\mathrm{Li}^{\prime}\right.$ or $\mathrm{PF}_{6}{ }^{-}$ doping) and the lower peaks $(\sim 3.4$ and $\sim 2.8 \mathrm{~V})$ arc for reduction ( $\mathrm{Li}^{\prime}$ or $\mathrm{PF}_{6}^{-}$dedoping). The potential of oxidation peak in Pani-HCl system is slightly higher than that of Pani$\mathrm{LiPF}_{6}$ system. Whilc. the reduction peak in Pani- $\mathrm{HCl}$ system shows slighty lower potential than that of Pani-LiPF system.

Figure 3 shows the discharge and cyele-life characteristics of $\mathrm{Li} / / \mathrm{Pani}-\mathrm{HCl}$ powder cell. in which the Pani is doped with protonic acid $\mathrm{HCl}$ and may play as a very good conductor. These discharge curves $\left(10^{\text {th }}\right)$ in Figure 3(a) resemble to the case of transition metal oxide clectrode in conventional lithium ion secondary battery. The nominally operating voltages of these cells may be approximated to almost $3.3 \mathrm{~V}$ in spite of different contents of conductor. Since Pani- $\mathrm{HCl}$ itsclf shows a good conductivity $(\sim 5 \mathrm{~S} / \mathrm{cm})$. it does not need any conductor and its active mass would be relatively decreased if adding the unnecessary conductor. On the other
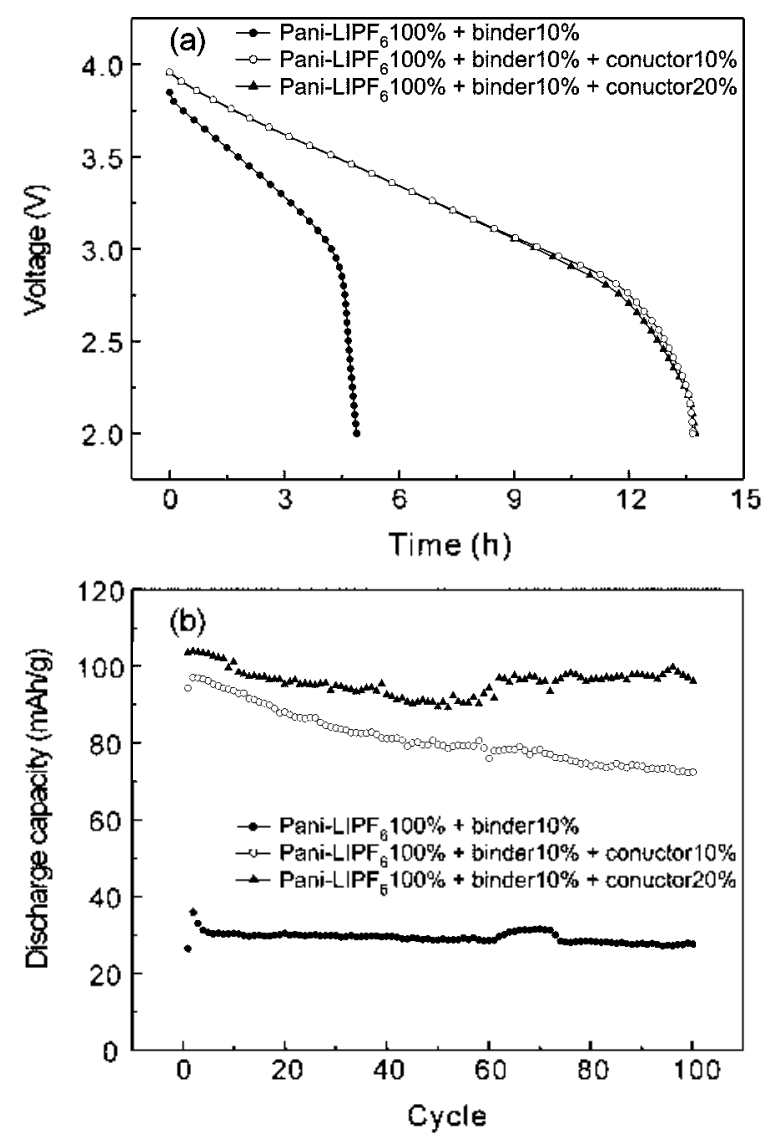

Figure 4. (a) Discharge curves and (b) cycle lite of I. $1 /$ Pani-I.iPF powder when cycled al $0.05 \mathrm{~mA} / \mathrm{cm}^{2}$. The amounds of electrodes are $32.08 \mathrm{mg}(\bullet 29.46 \mathrm{mg}$ ( ) , and $27.290 \mathrm{mg}(\Delta)$, respectively:

hand. the specific discharge capacitics of these compositions are similar to other compositions in Figure 3(b). but samples with $10 \%$ and $20 \%$ conductors show a little larger than that of no conductor. The highest discharge capacity is almost 50 $\mathrm{mAl} / \mathrm{g}$ at $100^{\text {th }} \mathrm{cyclc}$.

Lithium salt doping instcad of protonic acid doping into Pani is very important sinec the protonic ion would afrect the electrochemical reaction in the cell. Therefore. some previous results ${ }^{1.15}$ might be reasonable that the doping by nonprotonic agent could improve the electrochemical propertics. Figure 4 shows the discharge curve $\left(10^{\text {th }}\right)$ and the cycle life of $\mathrm{Li} / \mathrm{Pani}-\mathrm{LiPF}_{6}$ powder with varying the content of conductor. The discharge times of cells with conductor are longer than that of no conductor because of the low conductivity $\left(\sim \mathrm{l}^{-2} \mathrm{~S} / \mathrm{cm}\right)$ of Pani-LiPF 6 . Conscquently. the conductor becomes very important factor for the increase of discharge capacity in Pani-LiPF 6 system. On the contrary: the cell without conductor has larger internal resistance and thus results in short discharge time and small capacity. but the nominal operating voltage of almost $3.3 \mathrm{~V}$ is atlained. In Figure $4(\mathrm{~b})$. the composition of conductor $20 \%$ can bc chosen as the best condition showing the specific discharge capacity of almost $100 \mathrm{mAl} / \mathrm{g}$ at $100^{\text {th }} \mathrm{cyclc}$. This value is very similar with the capacity of lithium metal oxides. which are used currently as the positive electrode material of 

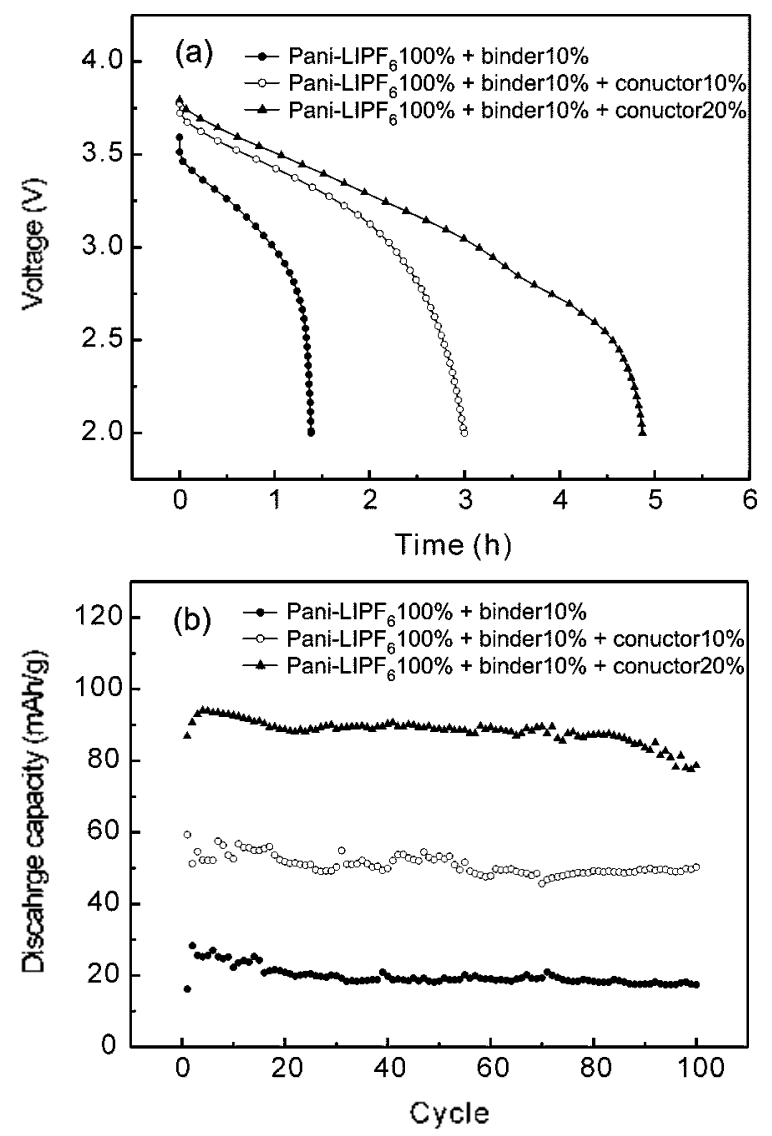

Figure 5. (a) Dischatoe curves and (b) cycle life of $I, \mathrm{i} / \mathrm{Tani}-\mathrm{I}_{\mathrm{i}} \mathrm{PF}$, pouder when cycled at $0.125 \mathrm{~mA} / \mathrm{cm}^{2}$. The amounts of clectrodes are $30.81 \mathrm{mg}$ ( - ) $28.52 \mathrm{mg}$ ( 5 ), and $26.32 \mathrm{mg}$ (4), respectikely:

lithium ion secondary batterics. Therefore. this material has the possibility of using as an clectrode material in conventional battery.

Figure 5 is the same case as Figure 4 except different current density $\left(0.125 \mathrm{~mA} / \mathrm{cm}^{2}\right)$ applicd. With the increase in current density. the discharge time is decreased and the ohmic drop becomes larger. and thus the starting voltage under this current density becomes smaller as $\sim 3.75 \mathrm{~V}$ than when applying low current density. Consequently. the discharge capacity is also decreased due to small $\Delta \mathrm{V}$ (voltage difference belween stant and end of discharge). The specific discharge capacity of the cell with conductor $20 \%$ is almost $90 \mathrm{mAl} / \mathrm{g}$ at $100^{\text {thi }} \mathrm{cycle}$ (sce Figure $5(\mathrm{~b})$ ) in spitc of 2.5 times higher current density. compared to the case of Figure 4(b). We also know that the decrease of the specific discharge capacily of the cell with conductor $10 \%$ is considerably large.

For the comparison of powder electrodes. which are treated above. with the film electrodes. we also assemble the cclls of Pani films doped with $\mathrm{HCl}$ and $\mathrm{LiPF}_{6}$. Figure 6 shows the specilic discharge capacitics of Pani-HCl film. Pani-LiPF 6 film. Pani-HCl powder. and Pani-LiPF 6 powder over $30^{\text {th }}$ cycle. The specific discharge capacity of Pani- $\mathrm{HCl}$ film is continuously increased with cycling. The saturated capacity can not be oblained due to the continuous increase

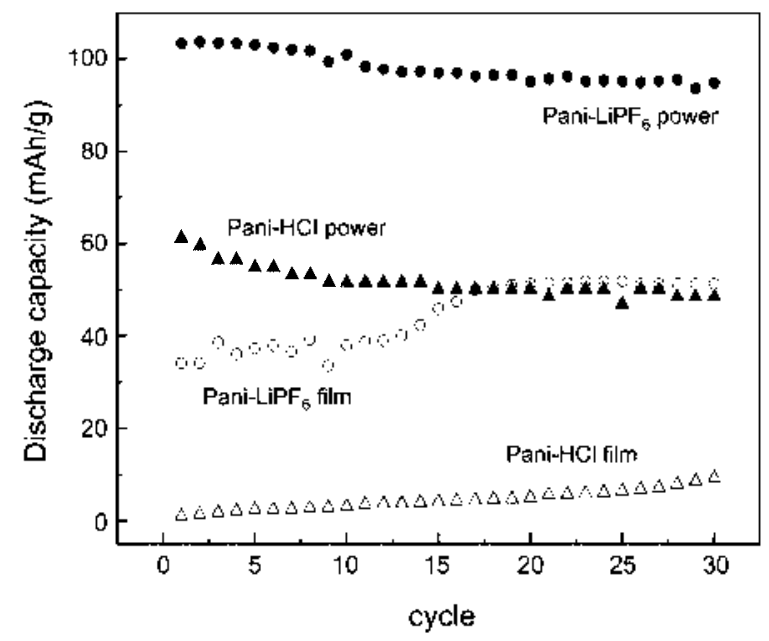

Figure 6. The specilic discharge capacities of Pani-I ICl film, PaniI.iPF, tilm. Pani-HCl powder, and Pani-LiPF $F_{6}$ powder until 30 cycles at $0.05 \mathrm{~m} / \mathrm{cm}^{2}$. This tilm is free standing tilm, which is not conlained any conductor and binder. The pouder electrode is composed of Pani-Lipl: powder, conductor, and binder $(10: 1: 2)$.

until the $30^{\text {th }}$ cycle. The specific discharge capacity at the $30^{\text {th }}$ cycle is $\sim 10 \mathrm{mAl} / \mathrm{g}$ which is only about $7 \%$ of the theorelical capacity $(142,6 \mathrm{mAl} / \mathrm{g}$ for a Pani unit doped by lithium salt) and the coulombic efliciency (the ratio of discharge capacity/charge capacity) $\sim 95 \%$. The specific discharge capacity of Pani-LiPF $F_{6}$ film increases and starts to salurate at $\sim 15^{\text {th }}$ cyclc. The saturated specific discharge capacity at the $30^{\text {th }} \mathrm{cyclc}$ is $\sim 50 \mathrm{mAl} / \mathrm{g}$ which is about $35 \%$ of the theoretical capacity and the coulombic efliciency $\sim 9 \%$. For the Pani-HCl powder cell. the specific discharge capacity slowly decreases with cycling and shows $\sim 50 \mathrm{mAh} / \mathrm{g}$ at the $30^{\text {th }} \mathrm{cyclc}$. which is about $35 \%$ of the theoretical value and the ellieicney $\sim 95 \%$. Finally. Pani-LiPF 6 powder cell shows the specific discharge capacity of $\sim 100 \mathrm{mAh} / \mathrm{g}$ at the $30^{\text {th }} \mathrm{cyclc}$. which is about $70 \%$ of the theoretical value and the efficiency $\sim 97 \%$. From these results. it is seen that the cell using powder electrode has the higher specific discharge capacity. which is rapidly stabilizcd. compared to film clectrode. For this reason. it may be regarded that the morphology or macroscopic structure of powder is very profitable for the effective electrochemical reaction in lithium sccondary battery using Pani clectrode.

\section{Conclusions}

The Li//Pani doped with $\mathrm{HCl}$ shows that the specific discharge capacitics of $10 \%$ and $20 \%$ conductors are a littc larger than that of no conductor. Since Pani- $\mathrm{HCl}$ has also a good conductivity $(\sim 5 \mathrm{~S} / \mathrm{cm})$. the Pani- $\mathrm{HCl}$ cell docs not need the conductor. The arerage voltage of these cells is almost $3.3 \mathrm{~V}$. The highest discharge capacity is almost 50 $\mathrm{mAl} / \mathrm{g}$ at $100^{\text {th }} \mathrm{cyclc}$. The Pani-LiPF 6 sample has lower conductivity than that of Pani- $\mathrm{HCl}$ onc. and thus the composition including conductor is needed to achicse the best performance. Li//Pani doped with $\mathrm{LiPF}_{6}$ and including 
$20 \%$ conductor achieves the best performance. Li//Pani doped with $\mathrm{LiPF}_{6}$ and including $20 \%$ conductor shows the remarkable performance of $\sim 90 \mathrm{mAl} / \mathrm{g}$ at $100^{\text {th }}$ cycle. Therefore. this material has the possibility of using as an clectrode matcrial in conventional battery. In addition. powder type electrode of $\mathrm{Li} / \mathrm{Pani}$ cell is proved to show higher specific discharge capacity and more rapidly stabilized than film type. This is due to the morphology or macroscopic structure of polymer.

Acknow ledgment. This work was supported by the Korea Ministry of Information Communication (MIC).

\section{References}

1. Ito, T.: Shrakewa. JI. Ikeda. S. J. Pollm. Sci. Pohm (7nem. 1974. I2, 11.

2. Nigrey, P. 1.: Maclnnes. I). J.., Nairns, 1). P. Macl Diamid, A. J. J. Hechochem. Soc. 1981. I28(8). 1651.

3. Panero. S.: Prosperi. P.: Bonino. F.: Scrosati. B.: Corradini. A.: Mastragostino. M. Ekctrokim. Acta 1987. 32(7). 1007.

4. Nishio. K.; Jujimoto, M.; Yoshinaga. N.: liurukawa. N.: Ando. ():

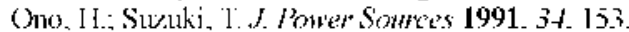

5. I oulty, R. I) : Shap, J. 11. J. (7hm. Phw 1979, 7/(3), 1211.

6. Jelle B. P. Hagen, (i.: Nodland, S. Wlectrochin icta 1993. $38(11) .1497$

7. Bao. Z.: Feng. Y.: Dodabalpu. A.: Raju. V. R.: Loringer. A. J. (htm. Mutkr. 1997. . (6). 1299.

8. Arbizzani. C.: Mastragostino. M.: Serosati. B. Homdhecth of

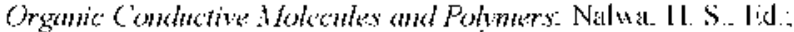
John Wilex \& Sons I td : 1997; Ch. 11

9. Osaka T: Naoi, K.: Ogano. S f. Llectrochem Soc. 1988. $13 \overline{3}(5)$. 1071 .

10. De Surville. R.: Josefowicz. M.: Yu. L. T.: Perichon. I.: Buvet. R. Electrochin. Acta 1968. /3(6). 1451 .

11. Osaka 1: Nakajima 1: Naoi 1: Onens, 13. 13. J. Electrochem. Soc. $1990,135(7) .2139$

12. Murray, I). P.: Kispert. I, 1).: Petrovic, S. Sy . 1/et 1989, 28(1-2). C269.

13. Yang. L.: Qui. W.: Litl. Q. Solid State Lonics 1996. 86-88.819.

14. Ryu. K. S.: Kim. K. M.: Kang. S. G.: Lee. G. T.: Too. J.: Chang. S. II. Snmh. Het. 20M0. HO. 213.

15. Ryu. K. S: Kim, K. M.: Kang S. G.: I ee G. J : Chang. S. II. Solid State lonics 2000. $135(\mathrm{I}-4), 229$

16. Genies. E. M.: Hany. P.: Santicr. C. J .tppt. flectrochem. 1988. IS(5). 751

17. MacDiarnid. A. G.: Chiang. J. C.: Richter. A. R.: Epstein. A. J. Sin. Mft. 1987, $1 S(1-3), 285$. 